DIGITAL COMMONS
@ UNIVERSITY OF SOUTH FLORIDA

Volume 7

Issue 2 Volume 7.2 (Fall 2017)

\section{ABO: Interactive Journal for Women in the Arts, 1640-1830}

\title{
Review of Locating London's Past and London Lives 1690 to 1800: Crime, Poverty and Social Policy in the Metropolis
}

Shawn W. Moore

Florida SouthWestern State College, shawn.moore@fsw.edu

Follow this and additional works at: https://digitalcommons.usf.edu/abo

Part of the Digital Humanities Commons, European History Commons, Literature in English, British Isles Commons, and the Other History of Art, Architecture, and Archaeology Commons

\section{Recommended Citation}

Moore, Shawn W. (2017) "Review of Locating London's Past and London Lives 1690 to 1800: Crime, Poverty and Social Policy in the Metropolis," ABO: Interactive Journal for Women in the Arts, 1640-1830: Vol.7: Iss.2, Article 6. http://doi.org/10.5038/2157-7129.7.2.1162

Available at: https://digitalcommons.usf.edu/abo/vol7/iss2/6

This Reviews is brought to you for free and open access by Digital Commons @ University of South Florida. It has been accepted for inclusion in ABO: Interactive Journal for Women in the Arts, 1640-1830 by an authorized administrator of Digital Commons @ University of South Florida. For more information, please contact digitalcommons@usf.edu. 


\title{
Review of Locating London's Past and London Lives 1690 to 1800: Crime, Poverty and Social Policy in the Metropolis
}

\author{
Abstract \\ Review of Locating London's Past and London Lives 1690 to 1800: Crime, Poverty and Social Policy in the \\ Metropolis \\ Keywords \\ digital humanities, archives, collections, database, GIS, manuscripts, London, digital projects, \\ geographical analysis \\ Creative Commons License \\ (c) (1) (9)
}

This work is licensed under a Creative Commons Attribution-Noncommercial 4.0 License 
Locating London's Past. Project Manager: Sharon Howard, University of Sheffield, 2011, https://www.locatinglondon.org/

London Lives 1690 to 1800: Crime, Poverty and Social Policy in the Metropolis. Project Manager: Sharon Howard, University of Sheffield, 2012, https://www.londonlives.org/

Reviewed by Shawn Moore

Florida Southwestern State College

Locating London's Past (LLP) and London Lives are digital resources created by Tim Hitchcock (University of Hertfordshire) and Robert Shoemaker (University of Sheffield). Managed by Sharon Howard (University of Sheffield), these projects aggregate data from several digital archival resources to produce a user-driven research environment for the study of eighteenthcentury London. Though each project has a different methodological framework, $L L P$ focuses on the spatial relationship between archival resources and the city of London and London Lives encourages users to analyze archival material focused on non-elite individuals of London, both projects aim to reshape how we understand the city and its inhabitants as a specific object of study.

These types of digital aggregators are reminiscent of projects like NINES or 18thConnect that aggregate metadata of digitized resources from multiple repositories. However, unlike these metadata aggregators, $L L P$ and London Lives allow users to interact with more than just metadata. In fact, both projects provide access to digitized material through connections to several other projects and databases. These datasets provide a base that users can build from either spatially in $L L P$ or through linked connections between archival documents like London Lives. Unfortunately, as robust as they are, these projects are limited by their methodological frameworks. Unless the user is searching for a specific target, the reach the project has to a general or research focused audience is limited. The lack of a clear relationship between the projects and that neither project has received a significant update since 2012 makes those limitations even stronger. Nevertheless, both projects provide ample space and opportunity if you know what you're looking for in advance.

With a partnership between the University of Hertfordshire, the Institute of Historical Research, University of London, and the University of Sheffield, $L L P$ hosts a GIS environment for visualizing geospatial data about London. The project is funded by the JISC eContent Programme 2011. At its core, $L L P$ is a dataset aggregator with a geospatial overlay for mapping data onto historical and modern maps of London. Aggregating datasets from the Old Bailey Online, the Centre for Metropolitan History, Estimating London's Population, Museum of London Archaeology (MOLA), and London Lives, LLP creates an environment for selecting data to be plotted onto maps. The maps include a GIS compliant version of John Rocque's 1746 map of London (indexed and created by MOLA) and additional overlays for "the first accurate OS map of London (1869-80) and maps available within a Google Map container. The data is mapped into the geospatial environment allowing users to visualize historical data on historical or modern map overlays. 
In simpler terms, users select datasets like the Hearth Tax data set from the Centre for Metropolitan History that allow users to search for names, number of hearths, gender, or ward/parish name. The records are aggregated and grouped. Users then select the data they want to visualize, which are mapped onto the GIS map and the corresponding modern overlays. Users can display the data as pins (like the modern Google Maps pins), blocks, or polygons and the user can further refine the visualizers by area or per hit. What users then have is that data plotted on the map, and they can select the map overlay they'd like to visualize whether the GIS Rocque's map to the OS map of London or modern Google Maps container with satellite and traditional map overlays.

LLP excels at producing geo-plotted datasets onto GIS maps and modern overlays. The methodology for mapping and how the maps were constructed is extensively documented on the project site, which is welcomed and much needed, but the question of why, why this resource is beneficial for understanding London's past is sadly pushed aside in favor of providing a robust yet complex environment for users. The project's framework and methodology are complicated because of the sheer number of working parts and datasets that are available. The project site tries to clarify the process of mapping these datasets.

However, without viewing the LLP WordPress site (https://locatinglondonspast.wordpress.com/) or the walkthrough videos (https://vimeo.com/album/1770693), new users to the project site are in for a surprise. The learning curve is steep, and the reasons for these particular maps are not as clear as one might like, but once you figure out how to use the datasets and map overlays effectively, it is well worth the effort (Fig. 1). Nevertheless, unless one is familiar with GIS maps and geospatial and relational datasets already, the digital burden may be too much to overcome. Researchers who are interested in visualizing historical data associated with London will be interested in this project, and it can provide a different way to understand data spatially.

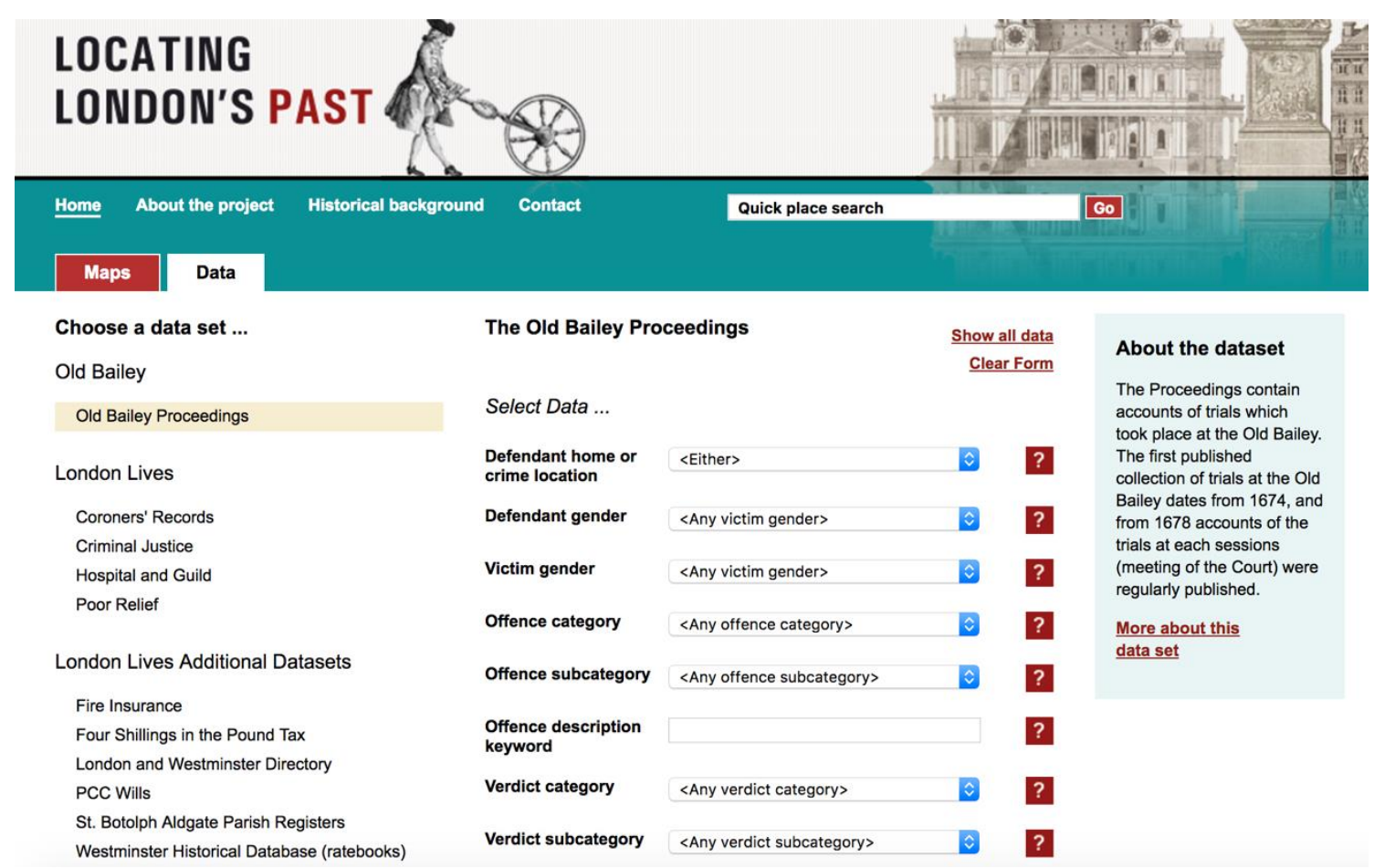


Figure 1: Users familiar with the datasets will find this project useful, but understanding the relationship between the data and the maps requires significant work.

Funded by the Economic and Social Research Council and supported by a partnership between the Humanities Research Institute and the University of Hertfordshire, London Lives is a primary source aggregator for the study of non-elite Londoners. Utilizing manuscript and printed pages from multiple London archives, which are supplemented by "fifteen datasets created by other projects," this resource provides access to primary material associated with "plebeian Londoners" and "provides access to historical records containing over 3.35 million name instances" ("About this Project").

The goal of the project is to re-focus the research on London lives away from non-elite Londoners to individuals who are underrepresented despite a wealth of archival material and datasets. London Lives hopes to provide a resource for users who want to research individuals in order to understand better the role and social practices of "plebeians" throughout London, without institutional restraints that limit how users link the datasets. To target non-elite individuals, London Lives aggregates material and records from areas like criminal justice systems, relief programs, and medical treatment records, and charity records. This focus on archival material and data produces a robust archive of primary sources, including digitized images, for the study of individuals and enables users to link records and compile information on individuals who are well documented.

Unlike Locating London's Past, this resource outlines the historical and archival significance for supporting research on London lives. According to the project site, this is a user-driven archival aggregator that allows users to focus their research on individual lives by examining how individuals utilized the agencies represented in the datasets. Users can access digitized manuscripts, digital images, and meta-data about individuals through keyword searches (Fig. 2). The user can then link records together and compile information and biographies of individuals. This process is meant to inform users and current research on how plebeian Londoners fit in to the historical space of London, which would reshape how we understand the social and economic place of these individuals in ways that match what we know of London elites. 


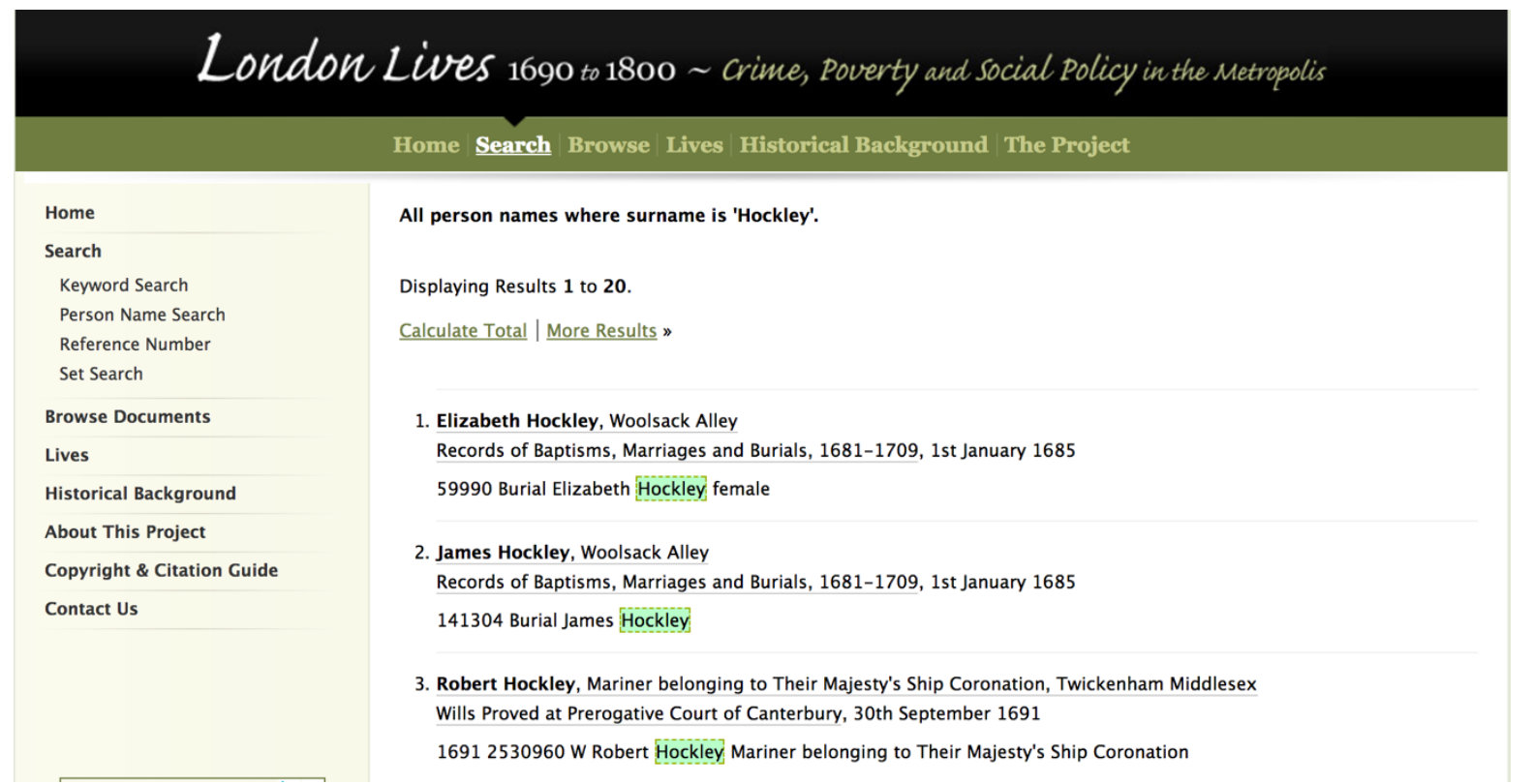

Figure 2: Users can focus their searches using surnames or given names. Linking these results gives users a valuable resource for building relationships via multiple archives. However, some results return only metadata while other results return digitized archival material.

The technical process for populating and creating the resource is well documented. The data that is incorporated into the project has been digitized while manuscripts have been manually typed through double rekeying. The digitized texts were encoded using XML to make names, occupations, places, and dates keyword searchable. Though errors are common and these methods for digitizing and marking information are sometimes faulty, the data available is sufficiently encoded to make the datasets useful. Information from the project also filters into and is searchable via Connected Histories, a digital resource archive from the study of British history sources, and Locating London's Past. This level of interoperability between resources and archives is important. It means multiple resources have access to this information and it means this information can be analyzed in a number of different settings and methodological frameworks.

London Lives is an important resource in that the data aggregated is substantial, but its focus is narrow, and it requires familiarity with the information represented. Searching a name can return multiple result pages, so sifting through the results can be cumbersome. However, a focused search returns clearer results that are useful for individuals researching specific names. Nevertheless, the access to the number of digitized manuscripts this resource provides is crucial and makes up for the lack of usability beyond the search function. 